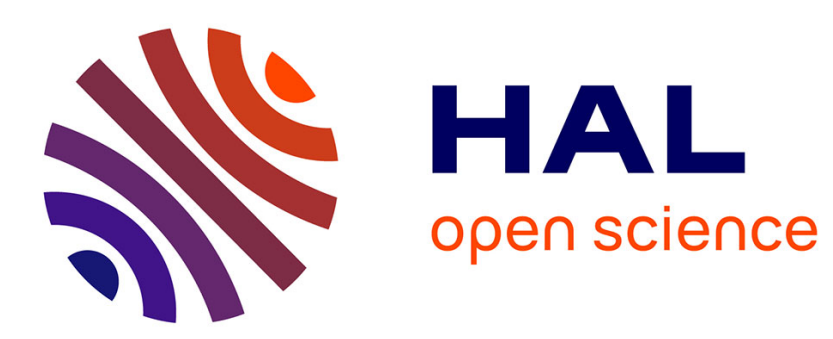

\title{
Black-boxing Sustainable Development: Environmental Impact Assessment on the River Uruguay
}

Nicolas Baya-Laffite

\section{To cite this version:}

Nicolas Baya-Laffite. Black-boxing Sustainable Development: Environmental Impact Assessment on the River Uruguay. Knowing Governance. The Epistemic Construction of Political Order, Palgrave Macmillan, pp.237-255, 2016, Palgrave Studies in Science, Knowledge and Policy, 978-1-137-51450-9. 10.1057/9781137514509_11. halshs-01281631

\section{HAL Id: halshs-01281631 \\ https://shs.hal.science/halshs-01281631}

Submitted on 9 Dec 2019

HAL is a multi-disciplinary open access archive for the deposit and dissemination of scientific research documents, whether they are published or not. The documents may come from teaching and research institutions in France or abroad, or from public or private research centers.
L'archive ouverte pluridisciplinaire HAL, est destinée au dépôt et à la diffusion de documents scientifiques de niveau recherche, publiés ou non, émanant des établissements d'enseignement et de recherche français ou étrangers, des laboratoires publics ou privés. 


\title{
Black-boxing Sustainable Development: Environmental Impact Assessment on the River Uruguay
}

\author{
Nicolas Baya-Laffite, PhD \\ LISIS Laboratoire Interdisciplinaire Sciences, Innovations, Sociétés \\ IFRIS Institut Francilien Recherche Innovation Société \\ Université Paris-Est
}

Authors'pre-print (pages of the published version are indicated in brackets).

Cite as: Baya-Laffite, Nicolas. 2016. "Black-Boxing Sustainable Development: Environmental Impact Assessment on the River Uruguay." In Knowing Governance: The Epistemic Construction of Political Order, edited by Jan-Peter Voß and Richard Freeman, 237-55. Palgrave Studies in Science, Knowledge and Policy. London: Palgrave Macmillan UK. https://doi.org/10.1057/9781137514509_11.

\begin{abstract}
This chapter offers an original account of Environmental Impact Assessment (EIA) as a technology that scripts collective action through black-boxing the politics of governance. After tracing the global trajectory of the instrument, the chapter looks at EIA struggles in the case of pulp mills on the River Uruguay. As actors seeking to halt projects because of their potential harmful impact follow the choreography of EIA, the authoritative governance script is reinforced rather than undermined. There is a tragic aspect to this, in that those wishing to block a project are actually making it stronger. This points to a subtle de-politicization resulting from the evolution of instruments in use, and a need for their re-politicization.
\end{abstract}

Keywords: environmental impact assessment, pulp mills, best available techniques, blackboxing, governance script, social studies of politics, policy instruments, sustainability struggles

\section{Introduction: black-boxing governance in instruments}

Over 40 years of diffusion worldwide, Environmental Impact Assessment (EIA) has acquired an authoritative governance script that says that part of the decision-making process about the licensing or the funding of territorial development projects can be delegated to the instrument. Inscribed in applicable planning and development (hard and soft) law, regulations, and general technical reference documents, EIA affords its use for legitimizing and challenging decisions where a balance between competing environmental and developmental interests is to be struck. Initially associated with information provision for ecologically rational planning, EIAs became enshrined as a means, and ultimately a condition, for the substantiation of sustainable development and participatory governance, whatever these may mean (Cashmore et al. 2007).

Moving beyond debates on procedure and substantive outcomes, EIA is seen in this chapter as constituting a ritualistic device, affording, through a sort of choreography, a legitimate 
governance process before deciding on development projects with regard to their environmental consequences (cf. Feldman/March 1981; Strathern 2000; Wynne 2010). But exactly because of that, it is suggested, EIA also constrains governance into particular directions, including some degree of de-politicization and, eventually, contained politicization within EIA's governance script.

When put to work, EIA's governance script configures actors (Akrich 1992; Woolgar 1990), creating a structured space around the assessed development project. This is a space where decision-makers, developers, consultants, NGOs, and affected populations, among other concerned actors of diverse nature, are accommodated if they agree to play by the rules of the game, to engage in producing, exchanging, and criticizing scientific and technical information and associated political values about potential social and environmental impacts of decisions. EIA is thought to be in terms of both processes and products. The EIA process results in a series of translations (238>) of heterogeneous elements into inscriptions, including the impact studies produced by the project sponsor, all sorts of documents produced by consulted parties, and the final EIA report produced by the competent authority. All these EIA products are to be considered in the decision. While there is in general no substantive prescription as to what the content of decision should be, EIA, as has been shown (Holder 2006), is not politically and epistemically neutral in terms of the outcomes it favours, as it provides the developer, public or private, a privileged avenue for influencing the decision process through its expertise. Considering EIA's use for the legitimization of often controversial development projects, the question then is to what extent opponents to such projects, who wish to justify their concerns in public debate, are also willing and ultimately able to politically challenge the instrument's fundamental value beyond the specific circumstances of its utilization. This means moving from politicization of projects to politicization of EIA as a knowledge-based governance instrument for the legitimate conciliation between development and sustainability.

In this light, EIA is analysed here as a political technology, where the politics have to do with black-boxing of governance arrangements - de-politicization as a governance move - and counter-moves that cause re-politicization. Drawn from Science and Technology Studies (STS) (Callon 2001), the concept of black-boxing refers to an elementary form of reified power and social ordering. In the STS field, Actor-Network Theory (ANT) has used the concept in explaining, often through case studies, the processes by which facts and artefacts are made, how their validity and efficacy are established, how they diffuse, and how they resist challenges. ANT stories of black-boxing deal with trajectories of discovery and innovation, path dependence and deployment, and closure of socio-technical controversies (Bijker/Law 1992). They show how strong multi-actor-network stabilization in the process of nature/society construction results in the black-boxing of heterogeneous elements into standardized forms which ensure manipulation, mobility, and legibility of reality. Inside the black boxes, out of sight, there are arrangements and crystallized power relations that hold heterogeneous elements together. This allows actors to rely on the black boxes and use them as a resource for effective action, without having to continuously renegotiate everything. The result is temporary depoliticization of black-boxed parts of reality. Temporary, because black boxes have fissures, can be challenged in specific contexts and can eventually break, with some of their elements being exposed to partial re-politicization in controversy, before being blackboxed again (Callon/Latour 1981).

Black-boxing of parts of reality and associated processes of de-politicization and repoliticization can be observed in environmental governance through the production, diffusion, and use of policy instruments (cf. Lascoumes/ Galès 2005). This is the case with the EIA, a 
policy instrument which has so far escaped STS scholarship on co-production sites and processes (cf. Jasanoff 2004); (239>) only recently has some EIA scholarship drawn on STS approaches to develop EIA theory (cf. Cashmore et al. 2010). In keeping with this recent literature on the socio-political development of EIA, this chapter focuses on EIA struggles this is controversy about projects in which EIA's use is at stake - as valuable sites for learning about the black-boxed governance at work, as the knowledge that has been inscribed in EIA is tested and debated, at least partially. The following sections of the chapter first trace the trajectory of diffusion and evolution of meaning in EIA's black box of knowing governance arrangements, highlighting the construction of a vast actor-network enabling the instrument to work. Then, a rich case study about the EIA of pulp mills in Uruguay, on the boundary river with Argentina, allows examination of how the EIA's script operates as an obligatory passage point to legitimizing as well as challenging the contested industrial investment projects, structures collective action, and constrains its own partial politicization in debates about what meaningful EIA of projects for sustainable development is. Finally, some lessons on the effects of the EIA's way of absorbing politicization are drawn.

\section{Black-boxing and diffusing EIA's governance script for sustainable development}

Today, EIA is an essential moment in the governance of territorial development projects. More than 120 countries worldwide, many international environmental agreements, and the main development assistance organizations, have established some form of EIA requirement prior to licensing or funding decisions being made. EIA's current status, its standard procedural template, and its overall purpose are the result of a long trajectory of black-boxing and diffusion in the context of economic globalization. In what follows, this trajectory is retraced so as to characterize the EIA's standard procedural form, as it appears through and beyond the specific forms EIA takes in national, international, and transnational instruments.

\section{EIA's diffusion from US NEPA to transnational finance soft law}

The first EIA legal template was designed in the United States within a vast movement of policy rationalization. Driven by key figures of the American environmental movement and its representatives in Congress (Milazzo 2006), EIA was put forward as an innovative science and technology-based instrumental response to the emergence of the environment as a political object. Its so-called father, at least formally, was political scientist Lynton Caldwell, one of the main designers of the National Environmental Policy Act (NEPA), adopted in 1970. EIA was introduced in NEPA as an actionforcing requirement, namely, that federal agencies conduct an environmental assessment and disclose an environmental impact statement prior to deciding on projects, plans, and programmes, as a means to incorporating (p240>) integrated environmental protection in decision-making. Since the landmark Calvert Cliffs case (Calvert Cliffs Coordinating Committee, Inc. v. Atomic Energy Commission), NEPA litigation has provided environmentalists a key tool for temporarily blocking and sometimes modifying decisions on controversial projects. Thus, entrepreneurs, agencies, and environmental groups were given both an instrument and an arena for engaging in environmental struggles. The result was a learning and disciplining process leading to the naturalization of EIA as an unavoidable step in development decision-making.

International diffusion beyond NEPA began with the United Nations Conference on the Human Environment, held in Stockholm in 1972, where the idea of incorporating EIA in legislation raised much enthusiasm. With its aura of scientific and technical rationality, EIA was promoted as a universalizable instrument for implementation of the Stockholm principles at the project 
level, namely, preventive action based on science and technology and integrated rational environmental planning and management. Effective diffusion supported massive investments in normalization and institutionalization to create the material conditions for such global adoption. UN agencies and programmes, institutions of multilateral economic cooperation and development assistance, and some large NGOs (Hironaka 2002) have been the key, specific places where EIA knowledge and techniques were produced and transferred. Success has been remarkable. In the 1970s, EIA legal requirements were incorporated in about 20 industrialized and some developing countries. Many others would follow over the next few decades.

Since then, the legislative framework in the first EIA systems, especially in Europe with the adoption of the EIA directive in 1985, has undergone considerable revision, and its scope of application has been much extended in a process of governance learning and experimentation. Particularly, EIA incorporated sustainable development and public participation in its governance script of informing decisions. Calling for a balance among goals of social equity, environmental quality, economic efficiency, and (the nevermentioned goal of) political governability, the sustainable development concept was progressively enshrined and associated with EIA. The World Charter for Nature in 1982, the Brundtland Commission (World Commission on Environment and Development, WCED) in 1987, and the Rio Earth Summit (United Nations Conference on Environment and Development, UNCED) in 1992 constitute landmarks of such evolution. In 1987 the United Nations Environment Programme (UNEP) recommended in its general goals and principles for EIA that EIA be implemented 'with a view to ensuring environmentally sound and sustainable development'. Principle 17 of the 1992 Rio Declaration confirmed this by prescribing that 'environmental impact assessment, as a national instrument, shall be undertaken for proposed activities that are likely to have a significant adverse impact on the environment and are subject to a decision of a competent national authority'.

(p.241>) In parallel, international EIA duties were incorporated in international agreements, though with less precision as to their scope and nature in comparison with national EIA. With the governance of transboundary impacts becoming a core concern, practice led to the enshrinement of a customary duty of EIA before environmentally harmful activities with potential effects on other states' territories. Subsequent developments of enforceable international instruments agreed by the UN Economic Commission of Europe (UNECE), namely, the Espoo Convention on EIA in a transboundary context, reinforced and harmonized the normative content of EIA. However, application of these UNECE instruments remains limited to signatory countries. The International Court of Justice (ICJ), among other jurisdictions, contributed substantially to the evolution of EIA in general international law through several judgements. Most of these concerned disputes over sea and watercourse use, an issue that has posed complex problems given its cross-border nature. In each decision the ICJ confirmed EIA as a condition for sustainable development (Segger 2009). However, findings of breaches in EIA obligations have never led to stopping the disputed projects, with international judges always emphasizing monitoring over no-development options. EIA is about ensuring sustained development within certain limits, not stopping it.

The adoption of EIA in most developing countries took place mainly during the 1990s, often through their first environmental law(s), even if practices of EIA date back to the 1980s or even 1970s in some countries. Such development was not endogenous, but top-down: it resulted from the need to comply with requirements of international and national development assistance agencies (Modak/Biswas 1999). Formalizing the early practices, OECD recommendations issued in the mid-1980s that international donors require borrowers to undertake EIA for 
projects entailing significant impacts consolidated the trend. EIA was progressively inscribed in soft law standards governing the transnational level: operational policies, guidelines, principles and codes of conduct for biand multilateral development agencies, investment banks, and multinational companies.

The World Bank has played a key role, even if the formal incorporation of EIA in its funding procedures came about only in the 1990s, in the aftermath of major controversial projects such as the Narmada Dam in India. The crisis this project entailed marked a turning point in the life of the Bank, a turn evidenced by the slogan 'don't get zapped by the Narmada effect, do your EIAs', now used in Bank staff's training seminars (Goldman 2006, 153). Since then, the World Bank requires not only the adoption of EIA by its client countries but also a mandatory internal EIA of its own project financing. Moreover, the establishment of the operational policy on environmental assessment (OP 4.01) in 1998 provided specific points at which potentially affected populations and concerned NGOs could officially participate in the EIA process early on in the project funding cycle. This reform was a major success. A huge transnational consulting industry and network of NGOs has (p242>) developed around the EIA practices of the World Bank, and with it, EIA practices and guidance issued by the Bank have now become a global benchmark. This has made the Bank a nearly unchallengeable authority in this respect.

In keeping with this evolution, EIA became a way for private sector governance to reduce economic risk. This flipped the purpose of EIA from environmental protection against business interests to the protection of business against environmental interests. Initially applied to major national infrastructure projects, such as hydroelectric dams, EIA in developing countries increasingly involved large, private, direct foreign investment projects in various sectors. Blamed for their responsibility in the ecological crisis, transnational companies operating in environmentally sensitive sectors reacted with a voluntary commitment to EIA in terms of corporate social and environmental responsibility. This is the private sector's form of sustainable development, as materialized, for example, in adherence to the World Bank's International Finance Corporation (IFC) Equator Principles, a benchmark for the financial industry to manage social and environmental issues in project financing (Lawrence 2009). In this context, EIA provides an arena linking the company's (or its consultants') expertise, public participation, and administrative decision-making, where economic actors seek to impose their own criteria for defining and managing environmental problems. Long considered as a constraint to avoid, EIA now appears to business as a valuable opportunity to control the social environment of (and thus potential challenges to) a project in order to reduce economic risks stemming from both environmental damage and social protest (Gunningham et al. 2004).

\section{EIA's black-boxed script of knowing governance}

EIA's successful diffusion was part of the development of a whole new institutional universe, including the creation of ministries in change of the environment, the emergence of specialized NGOs and private consultancies, and the development of a new academic transdisciplinary action-oriented field in university programmes and research, just to name a few elements. Beyond countries and organizations, a global community of practitioners, researchers, and users of EIA in multiple contexts has progressively taken shape. Since 1980 the International Association for Impact Assessment (IAIA) has been the main global forum for such community, with its own conferences, journals, and handbooks. Participants come from fields ranging from environmental sciences and engineering to law and political science. Members of this community hold many positions in a global network, the nodes of which are national and international organizations, public and private, in different realms dealing with EIA (cf. 
Voß/Simons 2014). This transnational community has played a major role in configuring the standard form of EIA, which can be summarized in a series of sequenced steps to which EIA should ideally conform.

The 'screening' of the project, the first step, answers the question: is a full EIA process necessary prior to deciding on the project? This implies (p243>) preliminary judgement of the significance of impacts to determine whether the project should be subject to a full EIA procedure. To avoid controversy about screening, it is common to have lists with categories of projects and standards and thresholds implying mandatory full or partial EIA.

The 'scoping' of the EIA, the second step, addresses the question: which impacts should the EIA consider, and to what temporal and geographical extent? This is where the limits of the application of preventive and precautionary rationales are defined in regard to efficiency criteria (Snell/Cowell 2006). Being of paramount importance to ensuring environmental and political effectiveness of EIA, public consultations at this stage are considered good practice.

The environmental impact study is the third step: what are the specific impacts that result from the project and what is their significance? How can they be prevented and mitigated? Answering implies characterizing both the projects' technical specificities and the baseline conditions of the social and natural environment; predicting the impacts using models and extrapolations; assessing their significance based on expert judgement; proposing reasonable alternatives, mitigation, and compensation measures; and defining monitoring and management plans so as to avoid a significant environmental impact. Multidisciplinary expertise is therefore required. The polluter pays principle demands that the burden of producing the studies be on the developer, public or private; the developer in turn often commissions the studies to specialized private consultancy firms or sometimes university-based consultancy services (Baya-Laffite 2008).

The fourth step is the review of the impact study by the competent authority and by the public. The question here is whether the study has assessed all significant negative impact and whether the project's mitigated environmental impact is acceptable. First, the competent authority must make sure that the impact studies are complete in all relevant aspects before disclosing a public summary, and sometimes the complete studies, for public review. Then, public consultations with affected populations are organized to inform about, and comment upon, the studies. This might include, in the case of transboundary impacts, bilateral consultations with other states and their populations, depending on the applicable legal framework. This is often the first occasion the public has the opportunity to engage in the EIA process and problematize it. However, it is also an occasion to determine which questions are considered legitimate in the public assessment, thereby separating political claims about the project's desirability from technically and scientifically grounded objections to the studies. Finally, the competent authority assesses all the information elicited in the process, including documents submitted in public consultations in order to produce the final EIA report with recommendations for the decision.

The sixth and final step is the decision. Very often, the decision whether to proceed with the project has been already made in prior stages of the (p244>) planning process. Thus, the question at this stage is less whether to grant development consent or funding, but rather, under what conditions, based on the conclusions of the EIA process, the development shall proceed. 
Two further steps can follow after the decision, if consent is granted, which function as extended EIA review. On the one hand, there is the follow-up to the EIA while the project is implemented and then when it is commissioned. The question here is whether the project has implemented all proposed mitigation measures and whether the impact conforms to predictions and assessments. This is done through a pre-commissioning audit and continuous monitoring. On the other hand, there is the possibility of legal review, if the EIA-based decision process is challenged in courts or via other quasi-jurisdictional grievance mechanisms. The basic general question here is which are the applicable norms and whether the decision-making process was effectively based on a full and meaningful EIA both in its procedural and in its substantive aspects, as required by applicable EIA norms.

Doing EIA means going through these steps that enable functional deployment, each anticipating specific questions and requiring answers based on specific kinds of knowledge and information (Glasson 2008). EIA thereby frames collective action by affording basic framings of how to deal with the issue at hand to produce nature/society orderings. This, in itself, is black-boxed knowing governance for environmental protection and sustained industrial development in a globalized market economy.

\section{EIA's black box at trial on the shores of the River Uruguay}

When EIA is done, there are debates about the assessed development project and the environment, which imply debates about scientific and technical knowledge. But there are also sometimes debates about EIA, which imply debates about governance knowledge. Some of these can problematize what meaningful EIA is, and thereby open up some elements of its basic governance script to debate. The case of contested pulp mill projects on the River Uruguay allows us to see the EIA's black box at work with its script structuring the debate in a complex environmental governance multilevel context (for a detailed analysis of the case and references to primary sources see Baya-Laffite 2015). The case is particularly interesting as it offers a view of EIA struggles around contested projects that were subject not to one, but three intertwined EIA processes: a national one in the licensing of the projects, a transnational one in the financing of the projects, and a bilateral, transboundary one within a water treaty binding two riparian states. EIA structured collective action and framed the debate at these three levels of governance/government, leading to specific outcomes. After presenting the context of the case, the EIA of the projects and the resulting de-politicization is examined to see how EIA becomes a matter of concern leading to some politicization. (p245>)

\section{EIA to protect the installation of pulp mills}

Uruguay's EIA regime was institutionalized in 1994. The Ministry of Housing, Land Planning and the Environment and, within it, the National Directorate for the Environment (DINAMA), have been in charge of undertaking EIA of land development projects since that time. The most important test for Uruguayan EIA since its adoption came with the first two foreign investments in pulp mills, totalling 200 million US dollars. In July 2002 ENCE, a Spanish multinational forestry product company, requested an environmental licence from the Uruguayan government to install a pulp mill with a capacity of 500,000 tons of Elementary Chlorine Free (ECF)bleached Kraft pulp per annum to be exported in the global market. The proposed site for the project was a large estancia where the company was already building a port terminal, ten kilometres from the city of Fray Bentos (20,000 inhabitants), on the shores of the River Uruguay, the natural border with Argentina. In October 2003, ENCE received an environmental licence. That month Botnia from Finland proposed a second ECF Kraft pulp mill. With an 
annual capacity of one million tons, it was to figure among the biggest in the world. The site was situated four kilometres from Fray Bentos and six kilometres from ENCE's site, also on the shores of River Uruguay. Botnia received its environmental licence in February 2005. In compliance with the 1994 EIA regulations both licensing decisions were preceded by the respective EIAs.

Step by step, the choreography of EIA structured the governance of the projects. As required by 'screening' provisions, ENCE and Botnia autoclassified their projects: both in category C for projects with potential significant impacts on the environment. DINAMA affirmed this classification. Therefore, there was no debate about the fact that both projects could have significant negative impacts on the environment and thus required a full EIA procedure, including public consultations prior to development consent.

The temporal scope of the EIA covered the full life of the projects; the geographical scope was limited to a radius of $40 \mathrm{~km}$ for ENCE and $60 \mathrm{~km}$ for Botnia around the projects sites. The scope excluded long-term and long-distance hypothetical or speculative impacts, as is common practice. DINAMA explicitly demanded that Botnia study the cumulative impact of the two projects (as by then ENCE had already obtained its licence). Regarding transboundary impacts, Uruguay considered that, since the projects were national, in spite of their siting on the River Uruguay, the EIA process should not be a transboundary one. Because of their siting, the projects were, however, subject to the River Uruguay Statute, signed by Uruguay and Argentina in 1975 to ensure the common rational and optimal utilization of the shared resource. The Statute does not mention EIA. However, both parties used EIA to comply with both procedural and substantive obligations, namely, to inform and consult each other about projects through the permanent river commission, and to take measures to ensure that water pollution is avoided. (p246>)

In this framework, Uruguay considered that the projects were national and its only obligation was to notify the river commission of the national EIA once completed.

To produce the impact studies, ENCE commissioned a consulting firm belonging to its owners; Botnia created its own EIA team and commissioned specific aspects of the studies to its regular consultants. The only significant impacts identified were social and economic, and were presented as highly positive for the Fray Bentos area and Uruguay. As regards siting alternatives, the studies justified not considering other sites on the grounds that Fray Bentos was strategic to the operation's needs: both companies had most of their plantations in the area; the area had the necessary infrastructure for the transportation of materials and products; and the river provided both the process water and the necessary receptor for the effluents, ensuring dispersal of pollution. As regards technological alternatives and mitigation measures, both studies proposed using Best Available Techniques (BAT) as defined by the European Union. Using BAT was presented as an alternative and as a mitigation measure in its own right in comparison to old, polluting bleaching techniques, still employed by local pulp and paper makers in the region. Both studies concluded by proposing operational monitoring and risk management plans.

DINAMA's task of reviewing the studies presented a major challenge, as it had no prior experience with this kind of large industrial projects. However, it sought to prove it was able to accomplish its mission by pointing out important deficiencies in the studies and requesting that ENCE and Botnia fill several information gaps, particularly concerning the techniques to be 
implemented and the modelling of pollution dispersal. Once these were addressed, DINAMA ordered disclosure of the studies' summaries for public review.

The sponsors organized public consultations in Fray Bentos, providing a first occasion for the developers, their consultants, Uruguayan authorities, and both the Uruguayan and Argentine constituencies to meet and exchange arguments. The fact that the public had been provided with the opportunity to be informed and comment upon the studies allowed the DINAMA to complete the EIA process and move forward. In its final EIA reports DINAMA concluded that the projects used BAT and that modelling showed that pollution concentrations would remain within applicable environmental quality standards. Therefore there would be no significant pollution. The environmental licences, fixing emission limits, and other conditions were based on this conclusion.

The studies produced by the sponsors were also to be reviewed by the International Finance Corporation (IFC). As the arm of the World Bank Group that finances private sector investments in developing countries, the IFC was requested by the two companies not only for funding but also for obtaining a certification that the projects complied with World Bank's environmental standards. Such compliance, in turn, was a condition to legitimize (p247>) funding by other private financiers that voluntarily adhere to IFC's Equator principles. In May 2005 IFC disclosed Botnia project's EIA documentation. In July 2005 it did so for the ENCE project. This implied IFC's review was finished, that the EIAs were deemed complete in all relevant aspects, and that the World Bank Directorate could decide on the investment. Works began employing thousands of workers and were to be completed in late 2007 for Botnia and late 2008 for ENCE. Fray Bentos was then to become one of the largest pulp making sites in the world.

\section{EIA struggles on the River Uruguay}

So far, our narrative account shows the EIA script functioning smoothly and successfully for the environmental legitimization of the projects. However, in the course of the EIA processes, between 2003 and 2005, debates, political, scientific, and technical, about the projects and the sustainable development of the River Uruguay arose. The result was a major conflict and EIA as the instrument to substantiate sustainable development was at its core. The debate started in Uruguay, where the EIA procedure was roundly criticized by NGOs arguing numerous deficiencies, biases, and flagrant collusion between the companies and the government. The DINAMA, they claimed, acted as a facilitator rather than as a controller of the projects, for it had no capacity to review the EIAs without the companies' expert guidance. This was the first effort to open up EIA's black box of governance. However, opposition in Uruguay remained limited. This was not the case on the Argentine side of the river.

Across the international bridge General San Martín, $30 \mathrm{~km}$ away from the mills' sites, is the city of Gualeguaychú (80,000 inhabitants). Alerted by Uruguayan and Argentine NGOs, Gualeguaychú residents engaged in a struggle to block the projects. Above all, they felt that the mills' projects were undesirable as a development path for the River Uruguay. This rejection was grounded on the following argument. The two projects proposed by European multinationals delocalizing their pollution to the global South would unavoidably produce toxic and noxious emissions. Situated at a very short distance and on a very sensitive area from both the social and environmental point of view, the pulp mills endangered existing uses of the river for leisure, tourism, and fisheries. The projects were, therefore, incompatible with Gualeguaychú's sustainable development. However, this basic argument needed to be 
technically and scientifically justified. And this is where the problem of challenging projects through the EIA script begins - with the condition to demonstrate 'the truth' about their expected impacts.

Considering they had been excluded from the Uruguayan EIA-based decision-making process, Gualeguaychú residents refused to give social licence to the projects. The opponents deployed a threefold strategy: First, they organized spectacular protests on the international bridge between Argentina and Uruguay to demand that Uruguay stop the installation (p248>) process so that the governments of the riparian states could engage in a meaningful EIA process in compliance with the 1975 River Statute procedural obligations. Second, they filed complaints dealing with the quality of the EIAs through different hard and soft law mechanisms. Finally, with support from environmental NGOs and university scientists, they sought to produce a 'people's EIA' (Manorom 2007) as a means to challenge the official EIAs of the projects. EIA appeared thus as the obligatory passage point to scientifically, technically, and legally grounding a fundamentally political opposition to the projects on the river.

The opponents' first march over the bridge, with about 800 participants, took place in October 2003 right before the licensing of ENCE. It put the issue on the bilateral agenda, leading the Argentine government to express its concern about the potential impacts as well as a potential breach of the River Statute. In April 2005 after the licensing of Botnia, a second march attracted 40,000 people. The result, this time, was to definitively enrol the Argentine government as an ally to the cause against the projects in Uruguay. Two EIA arenas opened up in May 2005: one transnational, governed by the IFC's operational policy, and one international (bilateral), governed by the River Uruguay Statute.

At the transnational level, the Argentine government demanded that the World Bank Group's Directorate not make any decision on funding without first studying the cumulative impacts of both projects. IFC was thus obliged to reopen its review process and conduct a cumulative impact study in July 2005. The stated aim was using additional detailed computer modelling to quantify impacts that, when combined, exceeded those impacts of each project considered separately. Scoping included, in principle, the study of impacts on Argentine territory. However, the lead consultant publicly stated that there would be no public consultations in Argentina, noting that the new study was in fact a pure formality, and that the World Bank had already decided to invest in both projects. The IFC did not take long to address the consultant's mistake and announced a change of consultants for the completion of the cumulative impact study. However, the IFC's initial consultants' mistake provided the opponents with a case. In September 2005 the Centre for Human Rights and the Environment (CEDHA), an Argentine NGO representing 40,000 residents of Gualeguaychú, filed a complaint with the Compliance Advisor Ombudsman Office (CAO), an independent body that allows individuals and communities affected by projects in which IFC is involved to bring their complaints directly. The aim was demonstrating the violation of the IFC's operational policy as a means to impede the funding. Acknowledging the plaintiffs' arguments, the IFC's Ombudsman concluded in November 2005 that the EIAs and the review process were not credible, that populations were not being meaningfully consulted, and that there had not been sufficient recognition of the legitimacy of worries and fears of the communities affected. Accordingly, it recommended that specific efforts be (p249>) implemented in order to ensure that people who believe that they will be impacted are able to have trust in the process as well as outcome of any additional studies. Along with a series of recommendations for the World Bank on reforms, which could help in enhancing environmental assessment practices, the CAO provided the IFC with clear guidelines to carry out a meaningful final cumulative impact study. 
The IFC's answer to CAO's report included engaging a conflict resolution organization to carry out a new consultation process on the cumulative impact study and an independent expert panel to assess the whole information elicited in the process. Two public consultations, organised by a Washington-based conflict resolution organization, took place in February 2006 in Buenos Aires and Montevideo (two other, planned in Gualeguaychú and Fray Bentos, had to be cancelled because of the political tension). The public meetings explicitly excluded all political debate and were framed as exclusively concerned with exchanging views about the accuracy of the draft cumulative impact study, disclosed in December 2005. The draft study concluded that there would be no negative cumulative impact on air and water quality and on tourism in the region, the main concerns of the public. The only negative cumulative impact was traffic congestion on the roads due to the circulation of trucks. All other cumulative impacts were social and economic, and positive. While there were many criticisms of the whole consultation process, some opponents were, nonetheless, willing to submit numerous comments advancing technical arguments, which were then incorporated in the studies' review. To the satisfaction of many of these opponents, the review conducted by a panel of two Canadian experts, confirmed in March 2006 that most of the technical critiques challenging the EIAs and the draft cumulative impact study were relevant and accurate. Particularly it noted that there were not sufficient guarantees that the mills would operate according to BAT. To the frustration of other opponents challenging the projects, however, it dismissed all claims that these deficiencies implied that the mills would have a significant negative impact. The experts concluded with a long list of issues to be addressed in the final cumulative impact study, which was commissioned to another Canadian consulting firm.

In parallel, at the bilateral level, negotiations on EIA were deployed since May 2005, when Argentina proposed to Uruguay that the two countries create a high-level diplomatic and expert group, Grupo Técnico de Alto Nivel (GTAN). The formal objective was to engage a bilateral EIA of the projects on the basis of the information provided by Uruguay. Though this information was considered too limited by Argentina, there were 12 meetings where Argentine and Uruguayan experts discussed the technical aspects of the projects, the baseline conditions, the modelling of pollution dispersion, and the assessment of the significance of impacts. However, the most controversial aspect was the analysis of alternative sites. For Uruguay, the decision about the siting of the mills on the shores of the river was sovereign and (p250>) not subject to negotiation. As works progressed, political tensions over the purpose of such an EIA became evident. This led GTAN to be disbanded in February 2006.

The River Statute provides that controversies unresolved through negotiation are to be taken before the International Court of Justice (ICJ, or the Court). In May 2006 Argentina instituted proceedings against Uruguay. Argentina's claim was that Uruguay had violated the River Statute because the projects had been authorized without following the mandatory bilateral procedure. This implied a meaningful EIA that took into consideration the transboundary environment. The question was, what determines the form, content, and scope of a meaningful EIA that complies with the Statute's procedural and substantial obligations? To avoid the fait accompli, Argentina requested provisional measures to stop the construction of mills. After hearing the arguments of the parties, the Court issued an order in July 2006 rejecting the request. The Court found that there was no proof of the imminence of the risk, that the impact studies ensured the sustainability of the projects, and that the alleged harm could not be deemed irreparable. With this decision, the opponents had to wait four years to obtain a ruling on the merits. 
In September 2006, while opponents begun systematically blocking the international bridge across the River Uruguay as a means of protest, the conflict came to a decisive point. On the one hand, IFC's consultants' final cumulative impact study was released and reviewed. All relevant issues highlighted in the first review, the two Canadian experts concluded, had been duly taken into consideration. This gave a green light to the funding of both projects; the Directorate of the World Bank decided that IFC should provide the requested funding. The opponents' efforts to interrupt the financing for the construction of the mills had failed. The result was not the expected halt of the projects' funding, but an opportunity for the IFC to correct the errors in compliance with its own operational policy. In sum, the legitimacy of the IFC's decision was the result of a cumulative impact study, the robustness of which was to a large extent the product of challenges. However, on the other hand, in favour of the opponents, ENCE announced unexpectedly at the same time that it had decided to relocate its plant. This was a major success for the opponents and was celebrated by those defending environmental protection interests. The company claimed, however, that the decision had no link whatsoever with the conflict or with pollution, but was due to the negative impact on the transport system, a conclusion stemming from the cumulative impact study.

The ICJ's decision on the merits of the case came out only on 20 April 2010 - that is, more than two years after Botnia's mill was commissioned, in November 2007. In its judgement, the ICJ (voting 13 to 1 ) said that Uruguay had violated procedural obligations under the River Statute, thereby impeding bilateral EIA. The Court enshrined the customary EIA procedural obligation, saying that a full EIA should have been available to Argentina before (p251>) Uruguay issued the licences. However, it also considered that the obligation to inform and negotiate on the basis of a bilateral EIA did not pre-suppose an obligation to come to an agreement and, therefore, Uruguay was allowed to proceed with the projects while the Court examined the case. On the other hand it also concluded, 11 to 3, that there were no substantive breaches, as there was no proof that the mill had breached environmental quality standards and national emission limits. All Argentina's claims about the inadequacy of Uruguay's EIAs were rejected. The Court said the scope of what the EIA Uruguay had to produce was determined by its internal EIA regulations, and not by international special instruments, which were not applicable. The Court found that there was no legal obligation to consult Argentine citizens, who had had the opportunity to express themselves when attending the meetings in Uruguay. Finally, the Court found that the predictions of the EIA were ex post facto correct, confirming thereby that mills complied with BAT. The fact that IFC and its experts validated the EIAs helped end the debate over the EIAs' quality. Considering that procedural breaches do not entail automatically substantive breaches, the Court concluded that ordering the dismantling of the Botnia mill was not necessary. Giving a special weight to proof resulting from the IFC's EIA review and post-operational monitoring, the Court refused to overturn the sovereign development decision of a party on a purely procedural basis. The Court ultimately confirmed the World Bank, through the IFC and hired experts, as an authority in defining sustainable development and how to achieve it though EIA. The Court's judgement, in April 2010, led to the restoration of bilateral relations with a joint monitoring plan of Botnia's mill on the River Uruguay in compliance with the River Statute. If there was pacification through a legal ruling, tensions persisted on the ground, as Botnia's pulp mill plans to expand its production made protests resurge and the controversy reemerged.

\section{Conclusion}

Far from being an obstacle to development, the deployment of EIA is a key condition of legitimating controversial investment decisions within a given, hegemonic development 
rationale. The naturalization of its script worldwide suggests that EIA is now part of globalized contemporary governmentality infrastructures. EIA has gained the ability to suggest and frame its use in a given situation beyond the intended purpose assigned to it by its designers or in its mode of use. Still, its workings and outcomes vary from one context to another. Variations depend on the assemblages in which it works. The EIA choreography is realized each time between contingencies and constraints. Project by project, the public avowal by the developer and the competent authority of the damage potentially caused, and the possibility of comment and revision, enables a balance between development and sustainability through the promise of technical mastery and monitoring. (p252>)

The account of EIA struggles in the pulp mills case allows a view of how the EIA functions as a black box of knowing governance for sustainable development, which can be partially opened in case of any controversy. In this case, there was no debate at all about the fact that EIA was required. But the debate and controversy over the projects gave place to a debate and controversy over EIA's implementation and purpose, and thereby to a debate about good environmental governance and the meaning of sustainable development in a complex multilevel and multi-actor context.

To open the pulp mills projects' black box, opponents were constrained to engage in a debate within the EIA process led by actors they did not trust: the companies and their consultants, the Uruguayan authorities, the IFC and their consultants, and even the Argentine government which was supporting them. Even if some elements of the governance script contained in EIA as the necessary instrument to ensure sustainability were partly problematized in different spaces and the ENCE project was ultimately relocated, the outcome was still somewhat tragic for the opponents. Their engagement with EIA to support their rejection of the projects led (and in a sense trapped) them to a de-politicization of the issues they raised. Moreover, opposing NGOs actually contributed to the technical improvement of the Botnia project through their critique of EIA (as regards scoping of EIA, the prediction of impacts, assessments of significance, identification of alternatives, and participation), while their original aim was to have it stopped. Participating, even reluctantly and sceptically, in formal consultation processes controlled by the project sponsors thus led to frustration of those aiming to challenge the projects on strict political grounds and furthered action through other means, namely, blocking the international bridge. Frustration has much to do with EIA generally limiting participation to commenting upon the study submitted by the developer. But it also has to do with EIA's capacity to absorb technical critiques, within certain limits set by the experts as to what is and what is not reasonable in terms of alternatives. There is also an overall tension resulting from the fact that this EIA debate came when many decisions, namely, the choice of the site and the technologies, had already been taken without public scrutiny and debate and with construction started. Debate took place in the shadow of growing irreversibility. If many of the technical critiques by opponents appeared to be relevant and accurate in the experts' view, these did not lead to a halt of the industrial projects, but instead helped to create an improved EIA process, which achieved a technically very robust result, legitimizing the projects as sustainable development. In this EIA space, the political debate about the development trajectories, their risks, and their governance in a transboundary context ended up being completely eclipsed by technical controversies that where the only ones recognized as legitimate. And the sponsors, through their experts, ultimately managed to address these.

While engaging with the EIA in an attempt to halt the investment projects, the legal action that the opponents took targeted, among other issues, (p253>) what they viewed as the inadequacy of the EIAs. The path of problematizing what meaningful EIA is, particularly in courts of justice 
or through soft law mechanisms, allowed opponents to re-politicize EIA. We see that the question of the conditions of realization and purpose of public and bilateral consultations within the EIA are central to this re-politicization. This kind of action, however, did not undermine the status of the instrument and how it absorbs politicization of implementation. Thus, EIA's black box may be opened, as in this case, giving rise to a debate on the sustainability of the industrial development project, though without questioning the fact that an EIA is the proper way to govern. Thus the learning that can occur when the black box of the instrument is opened up (or 'fractured') in controversy is limited to what is possible within the governance script of the present EIA, with its script being ultimately restored or renewed.

This leads to two key concluding points. The first is that there is a subtler de-politicization that occurs even when the black box of EIA is opened. There is de-politicization through blackboxing of governance in instruments and delegation to EIA's authoritative script. In the EIA struggles there is invited partial re-politicization. But there is a subtler de-politicization, where the first-round politicization is absorbed because of how the politics played out is scripted. The second key point is about learning about EIA governance. There is strong path dependency in the learning. This is because the governance script is also shaping the learning, which thus remains within the frame of the EIA rationale. But there could be another kind of more reflexive learning in knowing governance, where the actual value of EIA for its original or presently rephrased purposes is considered. This implies that in the life of governance instruments a reflexive moment should be built in to reflect on whether the structure and authority it has achieved are still appropriate. This may not be easy to do in the real world. It requires subtle politicization, rather than contestation about immediate sustainability and development issues.

The aim of this chapter was to show how instruments, in this case EIA, emerge, evolve, and stabilize, and then, as they are black-boxed, script actions. Opening up the black-boxing is a strategy for actors who wish to criticize projects for what their impacts might be. But they may still remain captured by the EIA governance script, so the black-boxing is only partially opened up. Maybe that is the best that is possible in current instrument-based knowing governance politics.

\section{References}

Akrich, M. (1992) 'The De-Scription of Technical Objects', in Bijker, W. E. and Law, J. (eds.) Shaping Technology/building Society: Studies in Sociotechnical Change (Cambridge, MA and London: MIT Press), 205-224.

Baya-Laffite, N. (2008) 'University and Local Government in Metropolitan Environmental Management', International Social Science Journal, 59(193-194), 381-396.

Baya-Laffite, N. (2015) Gouverner par la promesse du développement durable. Évaluation d'impact environnemental et meilleures techniques disponibles dans le conflit des usines de pâte à papier sur le fleuve Uruguay, $\mathrm{PhD}$ dissertation (Paris: École des hautes études en sciences sociales).

Bijker, W. E. and Law, J. (eds.) (1992) Shaping Technology/Building Society: Studies in Sociotechnical Change (Cambridge, MA and London: MIT Press).

Callon, M. (2001) 'Actor Network Theory', in Smelser N. J and Baltes, P. B. (eds.) International Encyclopedia of the Social \& Behavioral Sciences (Oxford: Pergamon), 62-66. 
Callon, M. and Latour, B. (1981) 'Unscrewing the Big Leviathan: How Actors Macrostructure Reality and How Sociologists Help Them to Do So', in Knorr Cetina, K. and Cicourel, A. V. (eds.) Advances in Social Theory and Methodology: Toward an Integration of Micro and Macro-sociologies (Boston: Routledge \& Kegan Paul), 277-303.

Cashmore, M., Bond, A., and Cobb, D. (2007) 'The Contribution of Environmental Assessment to Sustainable Development: Toward a Richer Empirical Understanding', Environmental Management, 40(3), 516-530.

Cashmore, M. et al. (2010) 'Evaluating the Effectiveness of Impact Assessment Instruments: Theorising the Nature and Implications of Their Political Constitution', Environmental Impact Assessment Review, 30(6), 371-379.

Feldman, M. S. and March, J. G. (1981) 'Information in Organizations as Signal and Symbol', Administrative Science Quarterly, 26(2), 171-186.

Glasson, J. (2008) 'Principles and Purposes of Standards and Thresholds in the EIA Process', in Schmidt, M. et al. (eds.) Standards and Thresholds for Impact Assessment. Environmental Protection in the European Union (Berlin and Heidelberg: Springer-Verlag), 3-17.

Goldman, M. (2006) Imperial Nature: The World Bank and Struggles for Social Justice in the Age of Globalization (New Haven and London: Yale University Press).

Gunningham, N., Kagan, R. A., and Thornton, D. (2004) 'Social License and Environmental Protection: Why Businesses Go beyond Compliance', Law \& Social Inquiry, 29(2), 307-341.

Hironaka, A. (2002) 'The Globalization of Environmental Protection: The Case of Environmental Impact Assessment', International Journal of Comparative Sociology, 43(1), 65-78.

Holder, J. (2006) Environmental Assessment: The Regulation of Decision Making (Oxford: Oxford University Press).

Jasanoff, S. (2004) 'Ordering Knowledge, Ordering Society', in Jasanoff, S. (ed.) States of Knowledge: The Co-production of Science and Social Order (London and New York: Routledge), 13-45.

Lascoumes, P. and Le Galès, P. (eds.) (2005) Gouverner par les instruments (Paris: Les Presses de Sciences Po).

Lawrence, P. (2009) ‘Equator Principles: Or How I Learned to Stop Worrying and Love Sustainability', Impact Assessment and Project Appraisal, 27(1), 3-6.

Manorom, K. (2007) 'People's EIA: A Mechanism for Grassroots Participation in Environmental Decision-making' Watershed, 12(1), 26-30.

Milazzo, P. C. (2006) Unlikely Environmentalists: Congress and Clean Water, 1945-1972 (Lawrence: University Press of Kansas).

Modak, P. and Biswas, A. K. (1999) Conducting Environmental Impact Assessment in Developing Countries (New York: United Nations University Press).

Segger, M.-C. C. (2009) 'Sustainable Development in the Courts: The Role of International Forums in the Advancement of Sustainable Development', Sustainable Development Law \& Policy, 10, 4-69. 
Snell, T. and Cowell, R. (2006) 'Scoping in Environmental Impact Assessment: Balancing Precaution and Efficiency?', Environmental Impact Assessment Review, 26(4), 359-376.

Strathern, M. (2000) 'The Tyranny of Transparency', British Educational Research Journal, 26(3), 309-321.

Voß, J.-P. and Simons, A. (2014) 'Instrument Constituencies and the Supply Side of Policy Innovation: The Social Life of Emissions Trading', Environmental Politics, 23(5), 735-754.

Woolgar, S. (1990) 'Configuring the User: The Case of Usability Trials', The Sociological Review, 38(1), 58-99.

Wynne, B. (2010) Rationality and Ritual: Participation and Exclusion in Nuclear Decision-Making (London and Washington, DC: Routledge). 